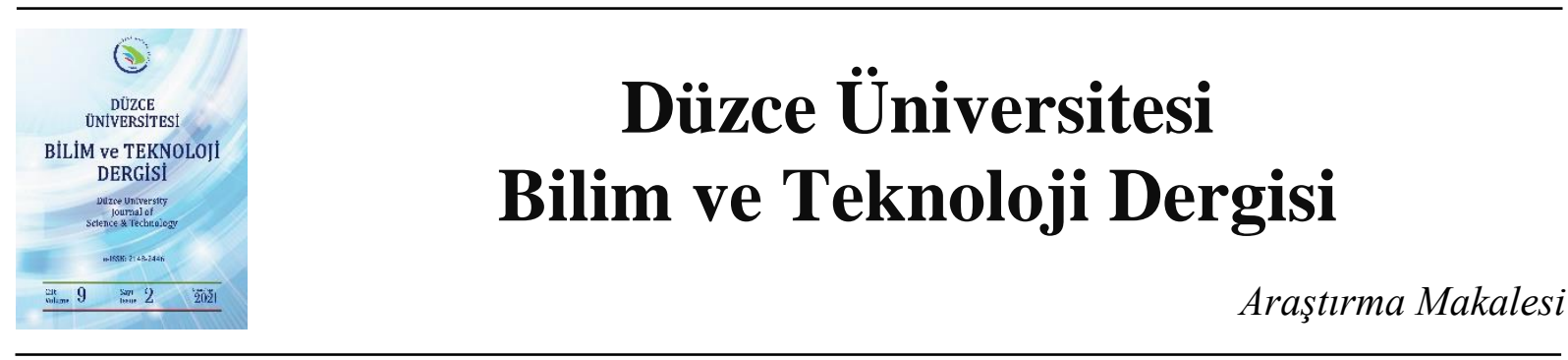

\section{Samsun, Bayburt ve Mersin İllerine Kurulabilecek Güneş Enerjisi Santrallerinin Modellenmesi}

\author{
Sezai AKKAYA ${ }^{\mathrm{a}, *}$, (D) Sibel AKKAYA OY ${ }^{\mathrm{b}}$ \\ ${ }^{a}$ Elektrik-Elektronik Mühendisi, Mersin, TÜRKIYYE \\ ${ }^{b}$ Ordu Üniversitesi, Fatsa Deniz Bilimleri Fakültesi, Deniz Bilimleri Teknolojisi Mühendisliği Bölümü, Ordu, \\ TÜRKIYE \\ * Sorumlu yazarin e-posta adresi: sezai.akkaya52@gmail.com \\ DOI: $10.29130 /$ dubited.785908
}

\begin{abstract}
ÖZET
Enerjinin temel kaynağı olan güneşi insanoğlu geçmişten günümüze doğrudan veya dolaylı olarak kullanmıştır. Sanayi devrimi ile birlikte insanoğlu bu enerji ihtiyacını yüzyıllar boyunca fosil kaynaklar ile gidermiştir. Ancak bu fosil kaynaklar çok büyük çevre problemlerine (küresel ısınma, buzulların erimesi, canlı türlerinin yok olması vs.) yol açmaktadır. Ayrıca fosil yakıtların kullanılması ile enerji yönünden devamlılığın sağlanması imkansızdır. Bütün bu sebepler yenilenebilir enerji kaynaklarından enerji elde etmeyi zorunlu kılmıştır. Bu çalışmada; Farklı güneş radyasyon verilerine sahip olan Türkiye'nin İki farklı bölgesinde bulunan Samsun, Bayburt (Karadeniz Bölgesi) ve Mersin (Akdeniz Bölgesi) şehirlerine şebekeye bağl $3 \mathrm{~kW}, 5 \mathrm{~kW}$ ve $10 \mathrm{~kW}$ kurulu güce sahip çatı tipi güneş enerji santrali modellemesi yapılmıştır. Ayrıca 7,224 kWh günlük enerji talebini karşılayacak şebekeden bağımsız çatı tipi Güneş Enerjisi Santrali (GES) modellemesi de yapılmışıtır. Bu modellemeler, PVGIS, PVsyst ve HOMER simülasyon programları ile yapılmıştır. Çatı tipi GES modellemelerinin üretim ve maliyet analizleri yapılarak yatırım yapılabilirlik seviyeleri incelenmiştir.
\end{abstract}

Anahtar Kelimeler: Güneş Enerjisi, Çatı Tipi GES, Maliyet Analizi, PVGIS, PVsyst, HOMER

\section{Modelling of Solar Power Plants that can be Installed in Samsun, Bayburt and Mersin Provinces of Turkey}

\begin{abstract}
Mankind have used the sun as the main source of energy directly or indirectly from past to present. With the industrial revolution, mankind have met this energy need with fossil sources for centuries. However, these fossil sources cause enormous environmental problems (global warming, melting of glaciers, extinction of living species, etc.). In addition, it is impossible to achieve energy sustainability by using fossil fuels. All these reasons make it compulsory to obtain energy from renewable energy sources. In this study; roof type solar power plant modeling is performed those installed capacity with $3 \mathrm{~kW}, 5 \mathrm{~kW}$ and $10 \mathrm{~kW}$ and connected to the city electrical network in two different regions of Turkey, which have different solar radiation data as Samsun, Bayburt (Black Sea region) and Mersin (Mediterranean region). In addition, off-grid roof type SPP (Solar Power Plant) modeling has been performed to meet the daily energy demand of 7,224 kWh. These models were made with PVGIS, PVsyst and HOMER simulation programs. The investment feasibility levels of the roof type SPP models are examined by making production and cost analyzes.
\end{abstract}

Keywords: Solar Energy, Roof Type SPP, Cost Analysis, PVGIS, PVsyst, HOMER 


\section{GIRIS}

Günümüzde insan medeniyetinin ihtiyaç duyduğu enerjinin \%80'inden fazlası fosil yakıtlardan karşılanmaktadır [1]. Ciddi çevresel sorunlara neden olmasına rağmen fosil yakıtların azalması enerji güvenliği açısından ciddi endişelere yol açmıştır [2]. Bütün bu sebepler yenilenebilir enerji kaynaklarından enerji elde etmeyi zorunlu kılmıştır. Yenilenebilir enerji kaynakları, doğal ortamdaki enerji döngüsünde, sürekli veya tekrarlanır akımdan elde edilen enerji veya kullanıldıkları hızda yeri doldurulan enerji akışları olarak tanımlanır [3]. Yenilenebilir enerji kaynakları: Hidrolik, güneş, biyokütle, rüzgar, jeotermal, dalga (Gel-Git) ve hidrojendir. Güneş enerjisi, kurulum ve kullanım kolaylığı olmasının yanı sıra çevreyi kirletmemesi ve zararlı atık oluşturmaması gibi özelliklere sahip bir yenilenebilir enerji kaynağıdır. Güneş enerjisinin avantajlarından biri de küçük güçlerde santral tasarımına imkan vermesidir.

Güneş enerjisi santral bileşenleri; güneş paneli, invertör, akü, AG dağıtım panosu, kablo, konnektör, çift yönlü sayaç, topraklama kazığı, sigorta, kaçak akım rölesi ve çatı konstrüksiyonundan vb. oluşmaktadır $[3,4]$.

Petrol ve doğal gaz rezervleri bakımından fakir bir konumda bulunan ülkemiz, enerji ham maddeleri ithalat1 maliyeti 2012 yılında 60 milyar Dolar, 2013 yılında 55.9 milyar Dolar, 2014 yılında 54.9 milyar Dolar, 2015 yılında 37.8 milyar dolar, 2016 yılında 27.2 milyar Dolar ve 2017 y1lında ise 36.8 milyar Dolar seviyelerinde olmuştur $[4,5]$.

17 Ocak 2018 tarihinde çıkarılan Elektrik Piyasasında Lisanssız Elektrik Üretimine İlişkin Yönetmelikte Değişiklik Yapılmasına Dair Yönetmelik ile çatı ve cephe uygulamalı elektrik üretim tesisi kurulumunun ve ihtiyaç fazlası üretilen elektriğin Devlet'e satılması yasal dayanağa dayandırılmıştır [6]. Meskenlerde bağlantı anlaşma gücü aşılmaması kaydı ile $10 \mathrm{~kW}$ 'a kadar (10 kW dahil) GES kurulumunun önü açılmıştır [6]. 10.05.2019 tarihli 30770 sayılı Resmi Gazete'de yayımlanan 1044 Sayılı Cumhurbaşkanı Kararı ile üretilen ihtiyaç fazlası elektrik enerjisi için EPDK tarafından ilan edilen kendi abone grubuna ait perakende tek zamanlı aktif enerji bedeli, tesisin işletmeye giriş tarihinden itibaren on yıl süreyle uygulanır maddesi ile ihtiyaç fazlası elektrik için uygulanacak fiyat tarifesi belirlenmiştir [7].

Güneş enerjisi sistemlerinde modelleme, maliyet analizi gibi simülasyonları gerçekleştirebilmek için birçok yazılım bulunmaktadır. Bu yazılımları; SAM, PVSyst, PVSol, PVWatt, HOMER, RETScreen, PVDesign-Pro ve TRNSYS diye siralayabiliriz [8].

Bu çalışmada, üç (3) farklı simülasyon programı (PVGIS, PVsyst ve HOMER) ve şebekeden bağımsız tasarımlarda matematiksel modelleme kullanarak elde edilen bulgular ve veriler hem karşılaştırılıp hem de birleştirilerek daha verimli bir sonuç elde edilmesi amaçlanmıştır.

Literatürde simülasyon programlarını kullanarak birçok GES tasarımı ve analizi yapılmıştır. Çakmak ve Altaş (2016), yayımladıkları makalede Trabzon'un güneş enerjisinden elektrik üretimi potansiyelini PVGIS, GEPA ve 2 farklı veri tabanı kullanarak ele almış ve Almanya ile karşılaştırmışlardır [9]. Haydaroğlu ve Gümüş (2016), yayımladıkları makalede Dicle Üniversitesi bünyesinde kurulmuş olan $250 \mathrm{kWp}$ 'lik güneş enerji santralinin simülayonu ve performans analizini PVsyst programı ile yapmışlardır [10]. Nurunnabi ve Roy (2015), yayımladıkları makalede Bangladeş'in güney kırsal bölgelerinde (Lobon, Chora, Khulna) şebekeye bağlı ve şebekeden bağımsız hibrit (FV ve Rüzgar türbini) santral tasarımlarının HOMER programı ile üretim ve ekonomik analizini yapmışlardır. Yapılan çalışmaya göre şebekeye bağlı hibrit santral tasarımı daha ekonomik bulunmuştur [11]. Rohani ve ark. (2010), yayımladıkları makalede elektrik şebekesinin ulaşamadığı yerler için FV ve Rüzgar türbini ana enerji kaynağ 1 , jeneratör ve aküler yedek enerji kaynağ ayrık santral modellemesinin ekonomik ve çevresel etkilerini incelemişlerdir [12]. Yadav ve ark. (2015), yayımladıkları makalede Hindistan'nın Hamirpur, Himachal ve Pradesh lokasyonlarında 1 kW kurulu güce sahip güneş enerjisi santrali tasarımını PVsyst kullanarak simüle etmişlerdir [13]. Kandasamy ve 
ark. (2013), yayımladıkları makalede Tamilnadu'nun güneyinde bazı yerlere 1 MW kurulu güce sahip güneş enerjisi santralinin kurulmasının uygulanabilirliğinin PVsyst kullanarak santralin enerji üretimi ve kurulum maliyetinin geri dönüşüm süreleri incelenmiştir [14]. Psomopoulos ve ark. (2015), yayımladıkları makalede Yunanistan'da bulunan 9,6 kW çatı tipi GES, 105,6 kW GES ve 98,4 kW kurulu güce sahip 2(iki) açılı güneş takip mekanizmalı santrallerin 24 aylık üretim verileri ile PVGIS, PVWatts ve RetScreen programlarından elde edilen verilerin karşılaştırmasını yapmışlardır [15]. Ceylan ve Taşdelen (2018), yayımladıkları makalede simülasyon ortamında PV*SOL, Helioscope, Polysun ve PVGIS PV simülasyon programları kullanılarak iklim verilerinin, yük taleplerinin ve temel sistem bileşenlerinin simülasyonu yapılıp, kurulu $1 \mathrm{MW}$ güneş enerjisi santralinin elektrik üretim verileri ile karşılaştırması yapılmıştır. Simülasyon verileri ile gerçek verilerin tutarlılı̆̆ 1 analiz edilmiştir [16]. Dondariya ve ark. (2018), yayımladıkları makalede Hindistan, Ujjain'de bir ev için şebekeye bağlı çatı tipi GES tasarımının, PV*SOL, PVGIS, SOLARGIS ve SISIFO FV simülasyon yazılımları ile üretim ve performans analizini yapmışlardır [17]. Literatürde yer alan çalışmalar yukarıda görüldüğü üzere daha çok modelleme, performans analizi ve gerçek bir santralle simülasyon programında elde edilen üretim değerlerinin karşılaştırması şeklindedir.

$\mathrm{Bu}$ nedenlerle bu çalışmada çatı tipi GES modellemelerinin üretim ve maliyet analizleri yapılarak yatırım yapılabilirlik seviyeleri incelenmiştir. $\mathrm{Bu}$ modelleme verileri ile güneş radyasyon verileri Türkiye ortalamasının altında olan Samsun şehri, güneş radyasyon verileri Türkiye ortalamasına yakın olan Bayburt ve güneş radyasyon verileri Türkiye ortalamasının üzerinde olan Mersin şehirlerindeki yatırım yapılabilirlik seviyeleri ortaya çıkarılmaya çalışılmışır. Güneş radyasyon verileri Türkiye ortalamasının altında, Türkiye ortalamasına eşit ve Türkiye ortalamasının üzerinde iller seçilerek Türkiye'nin 7(yedi) bölgesini kapsayacak verilerin elde edilmesi amaçlanmıştır.

\section{SAMSUN, BAYBURT VE MERSIN ILLERININ GÜNES ENERJISİ POTANSIYYELI}

Türkiye'nin Güneş Enerjisi Potansiyeli Atlasına (GEPA) göre, yıllık toplam güneşlenme süresinin 2.741 saat (günlük toplam 7,5 saat), y1llık toplam gelen güneş enerjisinin $1.527 \mathrm{kWh} / \mathrm{m}^{2}$ (günlük toplam 4,18 $\mathrm{kWh} / \mathrm{m}^{2}$ ) olduğu tespit edilmiştir [18,5]. Türkiye global radyasyon değerleri Mayıs, Haziran ve Temmuz aylarında en yüksek seviyede olurken, ortalama güneşlenme süreleri Haziran, Temmuz ve Ağustos aylarında en yüksek seviyede olmaktadır. Global radyasyon değerleri bölgelere göre incelendiğinde; İlk sırada Güneydoğu Anadolu Bölgesi ikinci sırada Akdeniz Bölgesi ve son sırada Karadeniz Bölgesi gelmektedir. Güneș enerjisinde öncü ülkelerden olan Almanya'nın aldığı en fazla 1şınım değeri olan yıllık $1200 \mathrm{kWh} / \mathrm{m}^{2}$, Türkiye'nin en az ışınım alan bölgesi olan Karadeniz Bölgesi'nin ışınım değeriyle hemen hemen aynidır [5].

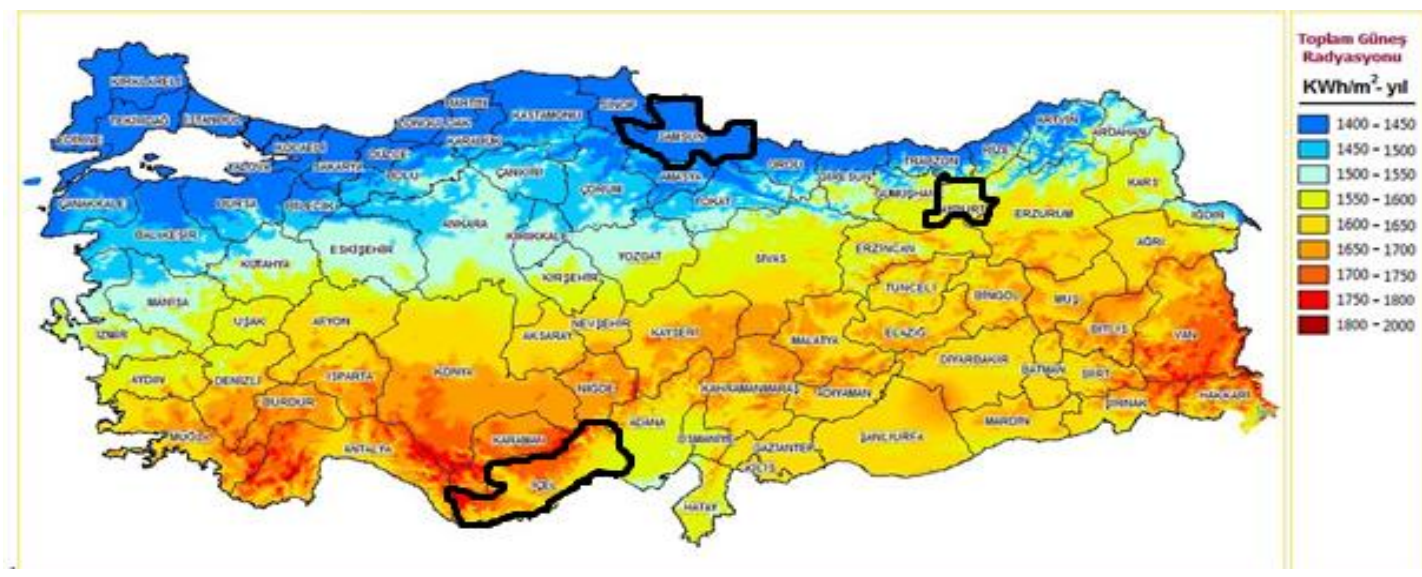

Şekil 1. Türkiye Güneş Enerjisi Potansiyeli Atlası(GEPA) [18]. 
Şekil 1'de görüldüğü üzere Samsun ili GEPA'ya göre $1.336 \mathrm{kWh} / \mathrm{m}^{2}$-yıl toplam güneş radyasyonu ile Türkiye ortalamasının altındadır. Bayburt ili GEPA'ya göre $1.530 \mathrm{kWh} / \mathrm{m}^{2}$-yıl toplam güneş radyasyonu ile Türkiye ortalamasına yakındır. Mersin ili GEPA'ya göre $1.626 \mathrm{kWh} / \mathrm{m}^{2}$-yıl toplam güneş radyasyonu ile Türkiye ortalamasının üzerindedir $[18,19]$.

\section{TASARIMLARI YAPILAN CATI TIPİ GÜNES ENERJISİ SANTRALLERINIIN KARSILASTIRILMASI}

İllerin yıllık toplam güneş radyasyonu ortalaması karşılaştırıldığında Mersin Türkiye ortalamasının üzerinde, Bayburt Türkiye ortalamasına yakın ve Samsun Türkiye ortalamasının altında kaldığ gözlemlenmiştir (Şekil 2). Bayburt ili Samsun ilinden yaklaşık \% 14,5 yıllık toplam güneş radyasyonuna sahipken, Mersin ili Bayburt ilinden yaklaş1k \% 6,3 yıllık toplam güneş radyasyonuna sahiptir (Şekil 2).

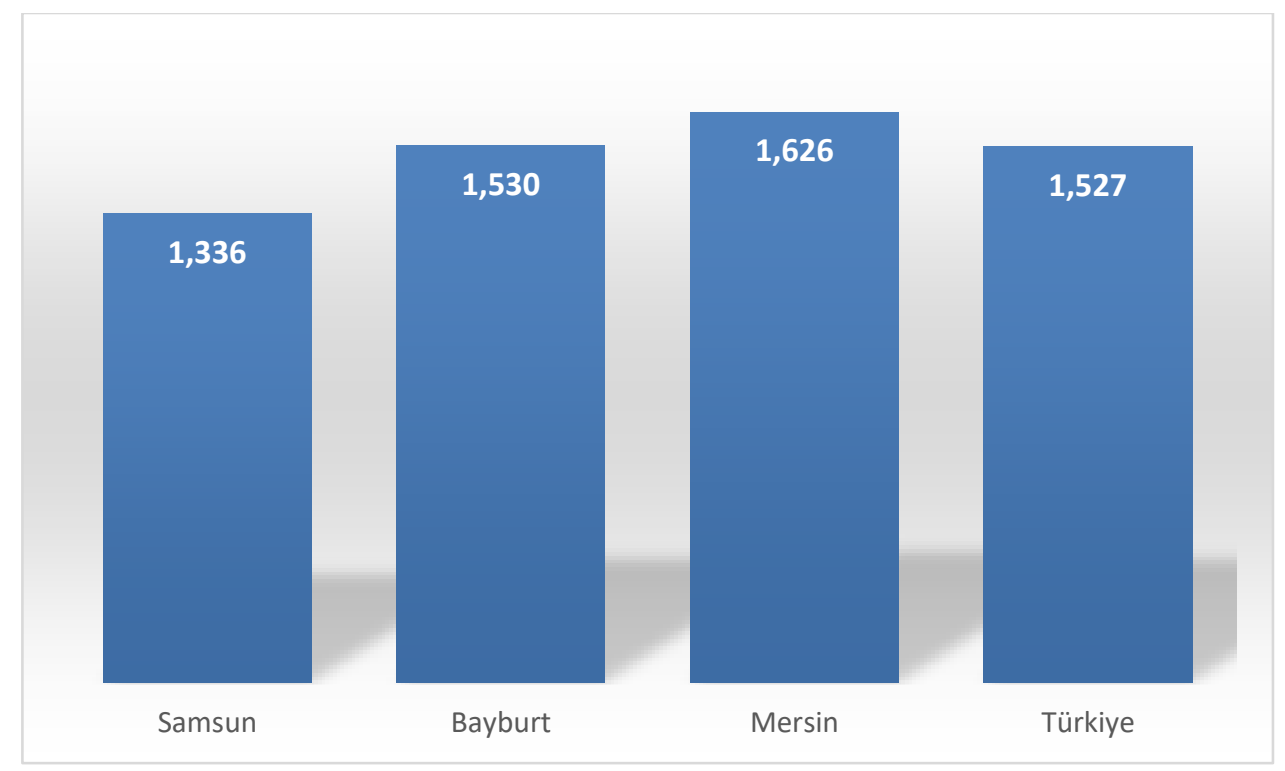

Şekil 2. GEPA'ya göre illerin yıllık toplam güneş radyasyonu ortalaması [kWh/m²]

12.05.2019 tarihli Resmi Gazete'de yayımlanan; Elektrik Piyasasında Lisanssız Elektrik Üretim Yönetmeliği ile aylık mahsuplaşma düzenlemesi yapılmıştır [20]. Böylece günlük mahsuplaşmadan aylık mahsuplaşmaya geçilerek GES üreticilerinin elde ettiği gelir arttığından santralin geri ödeme süresi azalmıştır. Aylık mahsuplaşma sisteminde bağlantı anlaşmasındaki sözleşme gücüne (Hanelerde bağlantı anlaşma gücü genelde $5 \mathrm{~kW}$ olmaktadır [19].) kadar üretim tesisi kurulmasına imkan tanınıyor [19]. Simülasyon yapılan illerde seçilen hanelerin günlük ortalama elektrik tüketimi 7,224 kWh ve yıl boyunca sabit kabul edilmiș ve tesis kullanım süresince günlük tüketimin değişmediği farz edilmiştir. 01.05.2019 tarihinde kurulan GES'lerde, 01.04.2019 EPDK elektrik tarifesi birim fiyatları kullanılmıştır. 01.05.2020 tarihinde kurulum yapılan GES'lerde, 01.04.2020 EPDK elektrik tarifesi birim fiyatlarının yıllar içinde değişmediği farz edilmiştir. Yıl boyunca meskenlerin iç tüketimlerinin yarısını şebekeden yarısının da güneş enerjisinden yaptığı farz edilmiştir. Şebekeden çekilen enerji miktarı dağıtım firmasına ödenecek çekiş yönlü dağıtım bedeli hesaplanırken kullanılmaktadır.

Enerji Piyasası Düzenleme Kurumu (EPDK) tarafindan 12 Mayıs 2019 tarihli Resmi Gazete'de yayımlanarak yürürlüğe giren Elektrik Piyasasında Lisanssız Elektrik Üretim Yönetmeliği ile:

- Yenilenebilir enerji kaynaklarına dayalı olarak gerçek veya tüzel kişiler tarafindan kurulan ve işletilen üretim tesislerinde aylık mahsuplaşma sonucunda her fatura döneminde şebekeye verilen ihtiyaç fazlası elektrik enerjisi görevli tedarik şirketi tarafından, on yıl süreyle satın alınacaktır [20]. 
Enerji Piyasası Düzenleme Kurumunca (EPDK) tarafından 26 Haziran 2019 tarihli Resmi Gazete'de yayımlanarak yürürlüğe giren güneş enerjisinde dayalı çatı ve cephe uygulamaları için aylık mahsuplaşmayla ilgili dağıtım tarifeleri ile:

- Mahsuplaşma kapsamındaki tüketim karşıllı̆̆ üretim için tüketim tesisinin abone grubuna özgü tüketici dağıtım tarifesinden $\% 50$ indirim

- Mahsuplaşma sonucu, tüketimin üretime eşit veya tüketimin üretimden fazla veya az olduğu durumlarda veriş yönünde dağıtım bedeli üretim tesisinin işletmeye giriş tarihinden itibaren 10 yıl süre ile \%100 indirimli uygulanacak

- Çekiş yönlü sistem kullanım bedellerinde ise tüketimin üretime eşit veya tüketimin üretimden düşük olduğu durumlar için \% 50 indirim uygulanacak iken, tüketimin üretimi aşan kısmı için ise ilgili tüketici grubu için belirlenmiş çekiş yönlü tüketici dağıtım bedelinde herhangi bir indirim uygulanmayacaktır [21].

Meskenlerde tüketilen enerji bölgelere göre farklılık göstermekte ve birçok etkene göre değişkenlik göstermekte olduğundan 2017 Ekim ayından beri ikamet etmiş olduğum konutun elektrik tüketim değerleri baz alınarak 3 il için de aynı tüketim değerleri yapıldığı farz edilerek kullanılmıştır. Modellemelerde baz olarak kullanılan Mersin'de 2 kişinin yaşadığ 1 mesken, 2019 yılında ortalama 6,262 $\mathrm{kWh} /$ gün, en düşük tüketim Haziran ayında $2,95 \mathrm{kWh} /$ gün ve en yüksek tüketim Eylül ayında 11,18 $\mathrm{kWh}$ /gün olarak gerçekleşmiştir. Samsun ve Bayburt illeri için de aynı tüketim değerleri yapıldığı farz edilmiştir. 2018,2019 ve 2020 yılındaki tüketim değerleri incelendiğinde; Ocak, Şubat, Ağustos ve Eylül aylarında en yüksek elektrik enerjisi tüketimi gerçekleşmiştir. Ayrıca 3 il için de üretim değerleri incelendiğinde Kasım, Aralık, Ocak ve Şubat aylarında güneş enerjisinden en düşük elektrik üretimi gerçekleşmiştir [19].

\section{A. ŞEBEKEYE BAĞLI ÇATI Tİİ GÜNEŞ ENERJisİ SANTRALLERIN KARŞILAŞTIRILMASI}

İllere yapılan şebekeye bağlı çatı tipi $3 \mathrm{~kW}, 5 \mathrm{~kW}$ ve $10 \mathrm{~kW}$ GES tasarımlarında geri dönüşs süresi hesaplanırken yıllık mahsuplaşma kullanılmıştır. Aylık mahsuplaşma olarak tasarımları yapmış olsaydık; Samsun yıl boyunca günlük tüketim 7,224 kWh/gün olduğu durumda sadece $3 \mathrm{~kW}$ GES tasarımında, Kasım, Aralık ve Ocak ayları hariç GES üretim değeri tüketilen enerjiden fazla olacak, yıl içinde tüketim değeri değişkenlik gösterdiği durumda ise Ocak ve Şubat ayları hariç GES üretim değeri tüketilen enerjiden fazla olarak gerçekleşecektir. Bayburt ve Mersin illerinde ise günlük tüketim 7,224 $\mathrm{kWh}$ /gün olduğu durumda 12 ay boyunca GES üretim değeri tüketilen enerjiden fazla olacak, yıl içinde tüketim değeri değişkenlik gösterdiği durumda ise Şubat ayı hariç GES üretim değeri tüketilen enerjiden fazla olarak gerçekleşecektir [19]. Hanelerin elektrik tüketim değerleri GES üretim değerlerini aştı̆̆1 durum sadece 2-3 ayla sınırlı kaldığı ve üretim ile tüketim arasındaki fark çok olmadığından işlem kolaylığı açısından yıllık mahsuplaşma tercih edilmiştir [19].

1 Nisan 2020 itibariyle EPDK tarafından belirlenen elektrik tarifelerine göre alçak gerilim (AG) mesken abonelerinin aktif tüketim perakende birim fiyatı $0,348202 \mathrm{TL} / \mathrm{kWh}$, dağıtım bedeli birim fiyat1 $0,225831 \mathrm{TL} / \mathrm{kWh}$ 'dir [22]. Yaklaşık \%22 vergi vb. eklenince $1 \mathrm{kWh}=0,71 \mathrm{TL}$ olmaktadır. Çekiş yönünden dağıtım bedeli fiyatı $0,113 \mathrm{TL} / \mathrm{kWh}$ 'dir. İhtiyaç fazlası üretilen elektriğin satış bedeli $0,348202 \mathrm{TL} / \mathrm{kWh}$ 'dir [7]. Dolayısıyla mevcut yatırım maliyetleri ve elektrik fiyatları dikkate alındığında özellikle güneş enerjisine dayalı üretim tesisleri için kişilerin aylık tüketimlerini karşılayacak büyüklükte üretim tesisi kurmasının yatırımın geri dönüş süresi açısından avantajı olacaktır.

SYNK $=$ YTTE*0,71 + YTNM*0,348202 - YTŞÇE*0,113

SGÖS $=$ TKM $/$ YNG 
SYNK: Santralin Y1llik Net Kazanc1 [TL]

YTTE: Y1llık Toplam Tüketilen Enerji [kWh]

YTNM: Yıllık Toplam Net Mahsuplaşma [kWh]

YTŞÇE: Yıllık Toplam Şebekeden Çekilen Enerji [kWh]

SGÖS: Santralin Geri Ödeme Süresi [Yı1]

01.05.2020 tarihinde seçilen illere kurulan şebekeye bağlı $3 \mathrm{~kW}, 5 \mathrm{~kW}$ ve $10 \mathrm{~kW}$ kapasiteli çatı tipi GES'lerin üretimleri, tüketimleri ve ürettiklerinden tükettiklerini çıkararak yapılan mahsuplaşma ile bulunduğu bölgede bulunan enerji dağıtım firmasına satıp gelir elde ettikleri üretim miktarları karşılaştırıldığında; En fazla üretim sırasıyla Mersin, Bayburt ve Samsun'da olduğu gözlemlenmiştir. Bayburt, Samsun' dan yaklaşık \%12'lik bir oranda daha fazla elektrik üretmekte, Mersin ise Bayburt'tan yaklaşık \%13'lük bir oranda daha fazla elektrik üretmektedir (Şekil 3).

Çatı tipi GES kurulumu yapılan illerde seçilen hanelerin günlük ortalama elektrik tüketimi 7,224 $\mathrm{kWh} / \mathrm{y} 1$ boyunca sabit kabul edilmiş ve tesis kullanım süresince günlük tüketimin değişmediği farz edilmiştir. Şebekeye bağl1 $3 \mathrm{~kW}$ ve $5 \mathrm{~kW}$ GES'lerde tek hanenin ylllık toplam tüketilen enerjisi $2.638,566 \mathrm{kWh} / \mathrm{yl}$ ve şebekeye bağlı $10 \mathrm{~kW}$ GES'lerde 2(iki) hanenin y1llık toplam tüketilen enerjisi $5.277,132 \mathrm{kWh} / \mathrm{yll}$ olmaktadır.

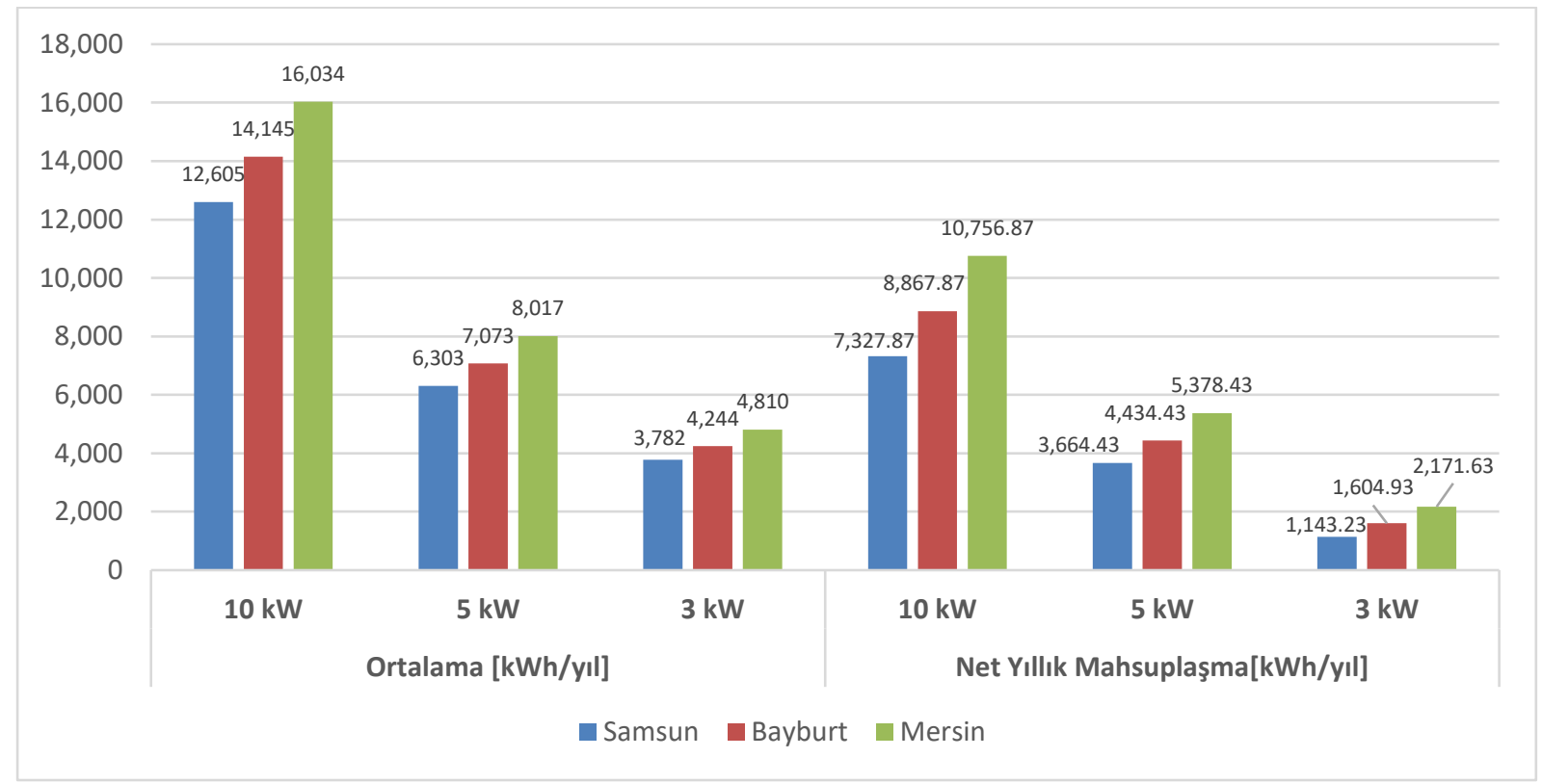

Şekil 3. İllerin yıllık güneş enerjisi üretim ve mahsuplaşma ortalaması [kWh/yıl]

Şekil 3'te verilen GES'lerin ylllk ortalama elektrik üretim değerleri PVGIS, PVsyst ve HOMER programlarından elde edilen üretim değerlerinin ortalamasıdır [19]. Şekil 3'te elde edilen verilere göre; Mersin iline kurulan şebekeye bağlı GES, Bayburt iline kurulan GES'e göre yaklaşık \% 13 daha fazla daha fazla elektrik üretmektedir. Bayburt iline kurulan GES ise Samsun iline kurulan GES'e göre yaklaşı \% 12 daha fazla elektrik üretmektedir. Şekil 2 ve Şekil 3 karşılaştırıldığında yıllık güneş radyasyon ortalaması fazla olan ilin yıllık ortalama daha fazla elektrik ürettiği ve iller arasındaki ortalama üretim değerleri farkının çok fazla olmadığı sonucuna varılmaktadır. Şekil 3 ’te elde edilen verilere göre; Mersin iline kurulan şebekeye bağlı GES, Bayburt iline kurulan GES'e göre yaklaşık \% 21 daha fazla net yıllık mahsuplaşma elde edilir. Bayburt iline kurulan GES ise Samsun iline kurulan GES'e göre yaklaşık \% 21 daha fazla net yıllık mahsuplaşma elde edilir. Mersin iline kurulan GES ile Samsun iline kurulan GES karşılaştırıldığında ise Mersin iline kurulan GES yıllık ortalama yaklaşık \% 27 daha fazla elektrik üretmekle birlikte yaklaşık \% 47 daha fazla net yıllık mahsuplaşma elde edilir.

Yapılan piyasa araştırmasına göre Türkiye'nin herhangi bir ilinde bulunan evin çatısına üretime hazır şekilde her şey dahil $3 \mathrm{~kW}$ kurulu güce sahip santral tasarımının maliyeti KDV dahil 6.000 Dolar, $5 \mathrm{~kW}$ 
kurulu güce sahip santral tasarımının maliyeti KDV dahil 8.500 bin Dolar iken $10 \mathrm{~kW}$ kurulu güce sahip santral tasarımının maliyeti KDV dahil 13.500 bin Dolar seviyelerinde olmaktadır. Dolayısıyla $3 \mathrm{~kW}$ kurulu güce sahip santralin birim maliyeti 2.000 Dolar $/ \mathrm{kW}, 5 \mathrm{~kW}$ kurulu güce sahip santralin birim maliyeti 1.700 Dolar/kW ve $10 \mathrm{~kW}$ kurulu güce sahip santralin birim maliyeti 1.350 Dolar $/ \mathrm{kW}$ olmaktadır. Buradan kurulu güç arttıkça birim maliyetin düştüğü ortaya çıkmaktadır. GES kurulumu yapan firmalardan edinilen bilgiye göre santrallerin 3 ayda 1 işletme bakımı ortalama 5 Dolar $/ \mathrm{kW}$ olmaktadır. Buradan hareketle $3 \mathrm{~kW}$ santralin 60 Dolar/Y11, $5 \mathrm{~kW}$ santralin 100 Dolar/Y1l ve $10 \mathrm{~kW}$ santralin 200 Dolar/Yıl bakım maliyetleri olmaktadır. Santralin daha verimli çalışması için periyodik bakımlarının yaptırılması önerilmektedir. Periyodik bakımlar, geri dönüş süreleri hesaplanırken ilk yatırım maliyetinin içinde olmadığı için hesaba katılmamıştır.

01.05.2020 tarihli dolar kuruna göre 1 dolar $=7$ Türk Lirasıdır. 01.05.2020 tarihi itibariyle kurulumu yapılan şebekeye bağlı $3 \mathrm{~kW}$ GES yatırım maliyeti yaklaşık 42.000 TL, $5 \mathrm{~kW}$ GES yatırım maliyeti yaklaşı 59.500 TL ve $10 \mathrm{~kW}$ GES yatırım maliyeti yaklaşık 94.500 TL olmaktadır (Şekil 4). İlgili hesaplamalar sonucu iller arası geri dönüşüm yılları azdan çoğa sırasıyla; Mersin, Bayburt ve Samsun olduğu tespit edilmiş ve iller arası geri ödeme süreleri farkı 1-2 yıl olduğu gözlemlenmiş̧tir (Şekil 4, Şekil 5).

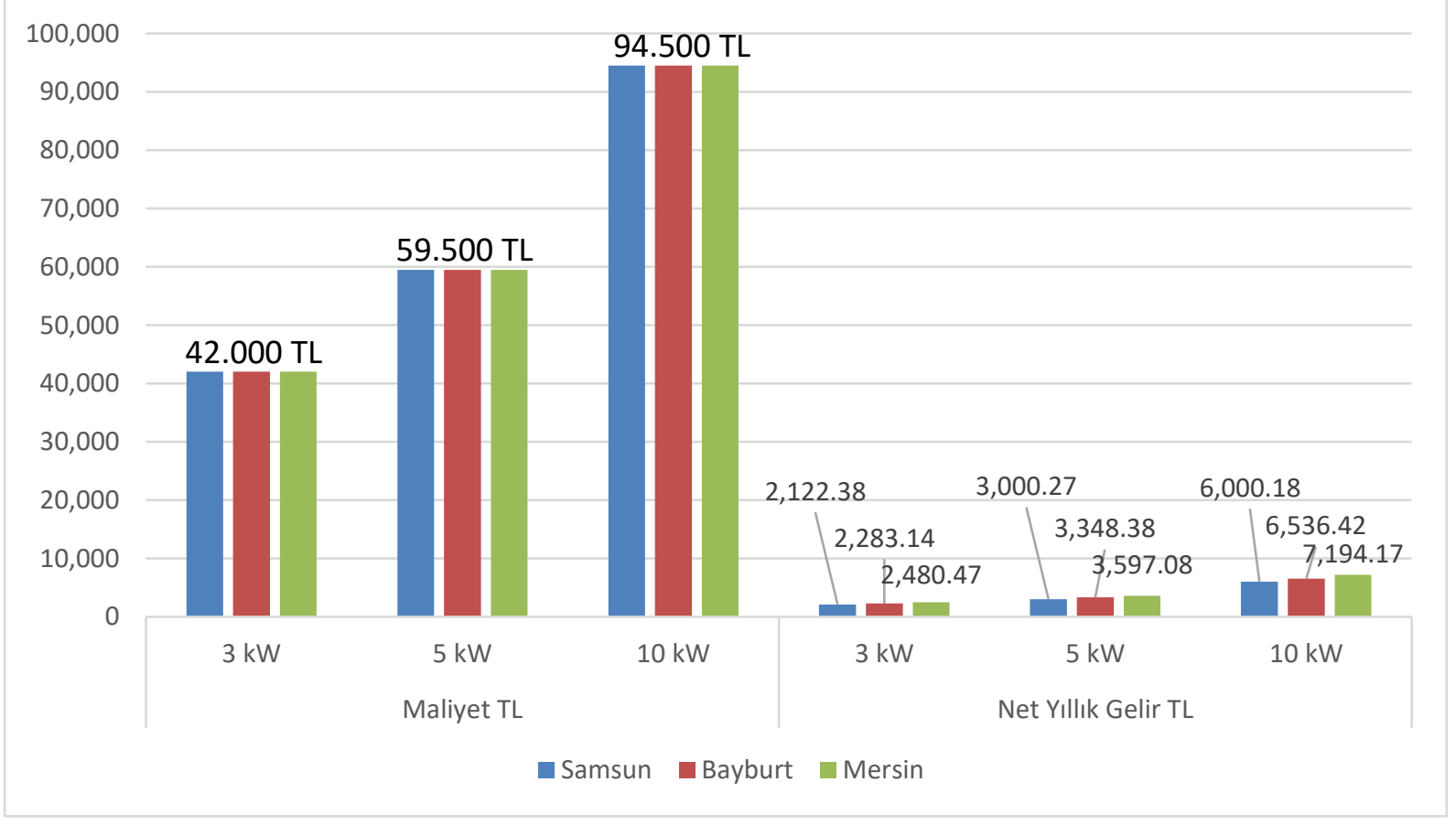

Şekil 4. İllere tasarlanan şebekeye bağlı santrallerin yaklaşık maliyet ve net yıllık geliri [TL]

Şekil 4 incelendiğinde Mersin iline kurulan şebekeye bağlı GES'ten elde edilen net y1llık gelir, Bayburt iline kurulan şebekeye bağlı GES'ten elde edilen net yıllık gelire göre yaklaşı \% 10 daha fazla olmaktadır. Bayburt iline kurulan şebekeye bağlı GES'ten elde edilen net yıllık gelir ise Samsun iline kurulan şebekeye bağlı GES'ten elde edilen net yıllık gelire göre yaklaşık \% 9 daha fazla olmaktadır. Mersin iline kurulan şebekeye bağlı GES'ten elde edilen net y1llık gelir, Samsun iline kurulan şebekeye bağlı GES'ten elde edilen net yıllık gelire göre yaklaşık \% 20 daha fazla olmaktadır.

Şekil 5 incelendiğinde illere kurulan $10 \mathrm{~kW}$ kurulu güce sahip santrallerin geri ödeme sürelerine göre daha iyi olduğu ve en avantajlı ilin Mersin olduğu ortaya çıkmıştır. Geri ödeme süresi en az olan Mersin, geri ödeme süresi en fazla olan Samsun'a göre yaklaşık 2,5 yıllık bir avantaja sahip olması iller arasında çok ciddi bir farkın olmadığını ortaya çıkarmaktadır. 


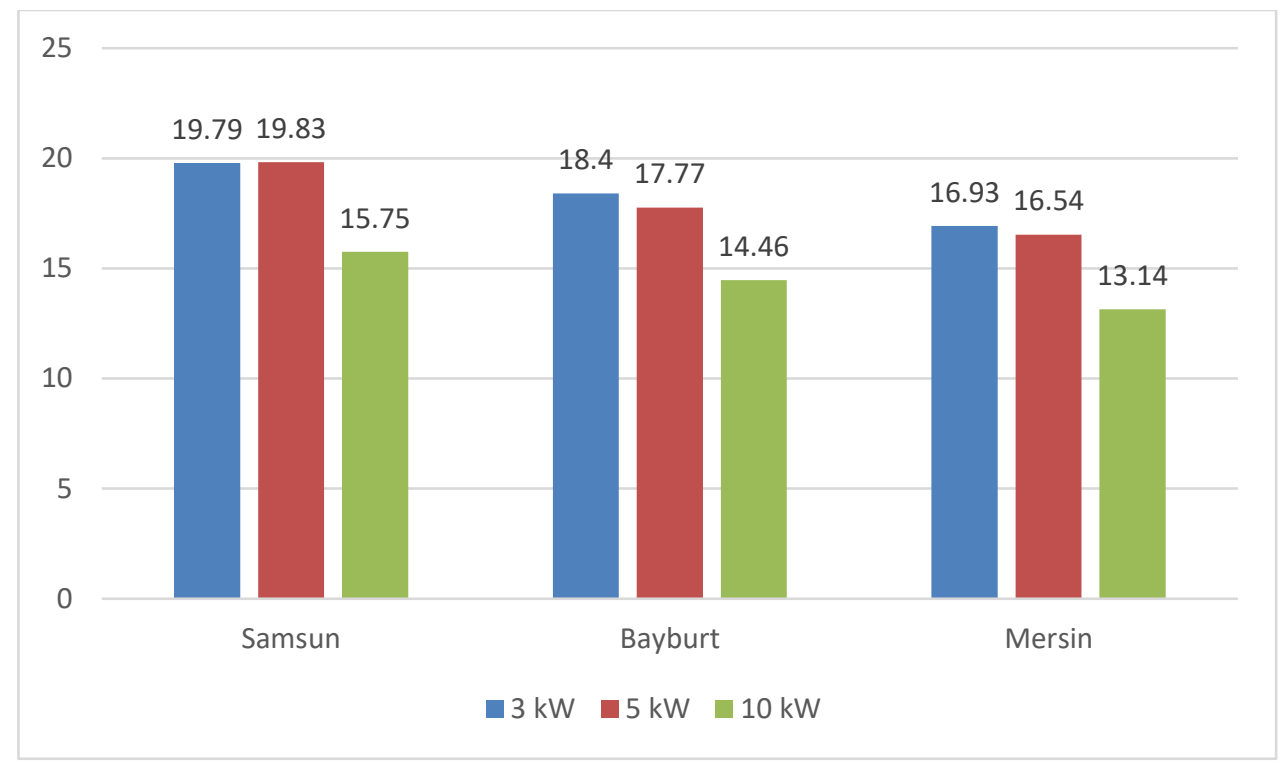

Şekil 5. Illere tasarlanan şebekeye bağll santrallerin geri ödeme süresi [Yıl]

01.04.2019 itibariyle EPDK tarafindan belirlenen elektrik tarifelerine göre AG mesken abonelerinin aktif tüketim perakende birim fiyatı $0,263304 \mathrm{TL} / \mathrm{kWh}$ ve dağıtım bedeli birim fiyatı 0,171147 $\mathrm{TL} / \mathrm{kWh}$ 'dir [23]. Çekiş yönünden dağıtım bedeli fiyatı $0,0855735 \mathrm{TL} / \mathrm{kWh}$ 'dir [7]. Yaklaşık \%22 vergi vb. eklenince $1 \mathrm{kWh}=0,53 \mathrm{TL}$ olmaktadır. İhtiyaç fazlası üretilen elektriğin satış bedeli 0,263304 $\mathrm{TL} / \mathrm{kWh}$ 'dir.

01.05.2019 tarihli dolar kuruna göre 1 dolar $=6$ Türk Lirasıdır [19]. 01.05.2019 tarihi itibariyle kurulumu yapılan şebekeye bağlı $3 \mathrm{~kW}$ GES yatırım maliyeti yaklaşı $36.000 \mathrm{TL}, 5 \mathrm{~kW}$ GES yatırım maliyeti yaklaşık $51.000 \mathrm{TL}$ ve $10 \mathrm{~kW}$ GES yatırım maliyeti yaklaşık $81.000 \mathrm{TL}$ olmaktadır.

$$
\begin{aligned}
& \text { SYNK }=\text { YTTE*0,53 + YTNM*0,3263304 }- \text { YTŞÇE*0,0855735 } \\
& \text { SGÖS }=\text { TKM } / \text { YNG }
\end{aligned}
$$

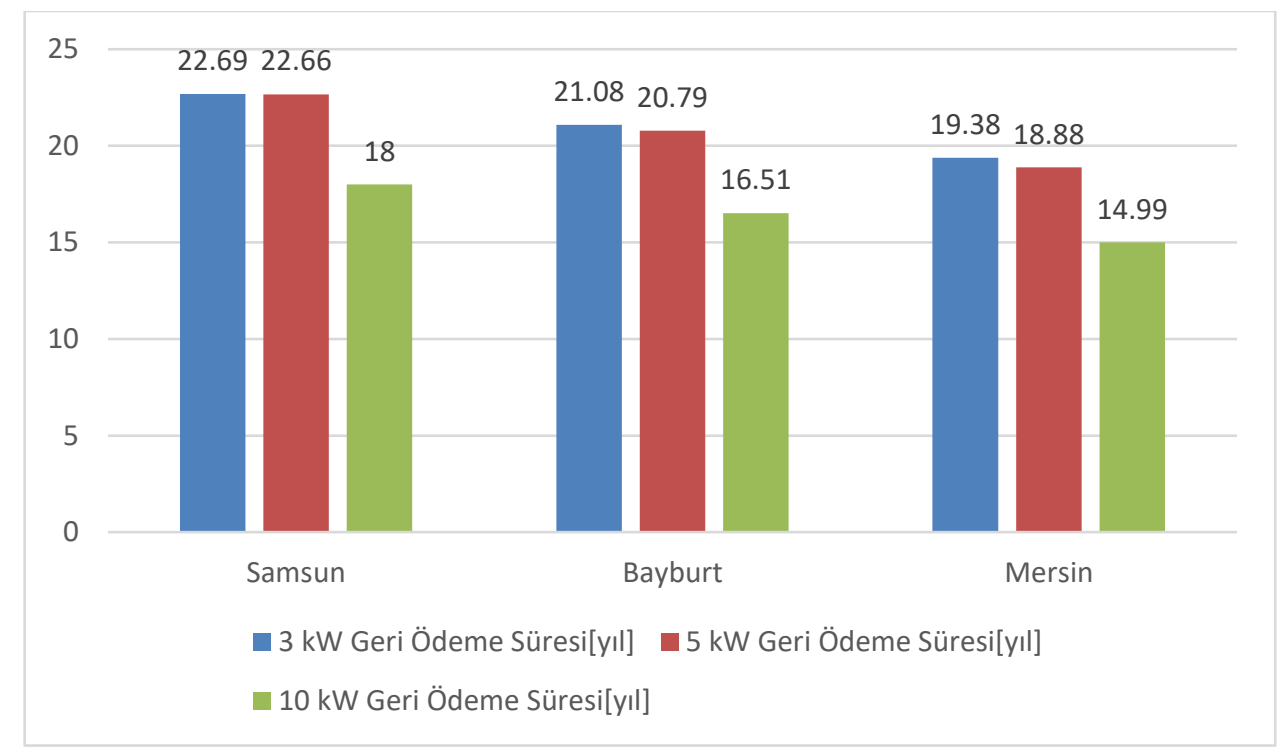

Şekil 6. 01.05.2019 tarihinde illere tasarlanan şebekeye bağll santrallerin geri ödeme süreleri [Yıl] 


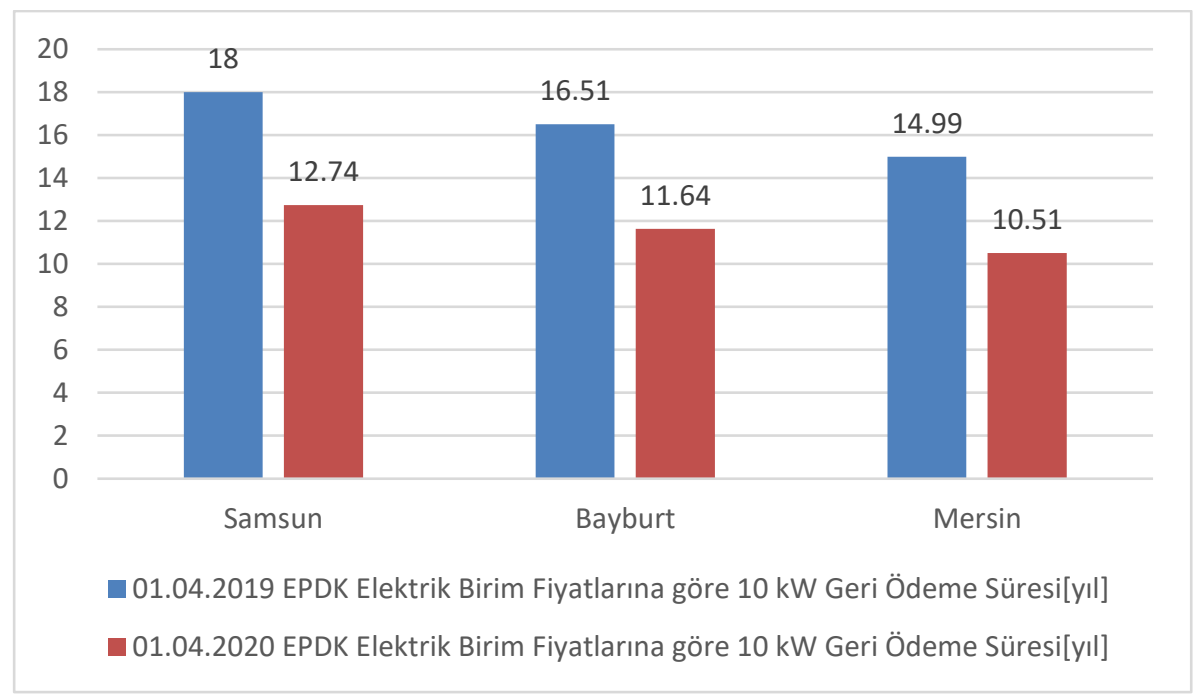

Şekil 7. 01.05.2019 tarihinde illere tasarlanan şebekeye bağlı $10 \mathrm{~kW}$ santralin 1 ylllı süreçteki geri ödeme sürelerinde meydana gelen değiş̧im [Yll]

01.05.2019 ve 01.05.2020 tarihlerinde yapılan tasarımlar karşılaştırıldığında 3 il için de aylık ve yıllık mahsuplaşma için en ideali $10 \mathrm{~kW}$ 'lık şebekeye bağlı GES tasarımı olduğu tespit edilmiş fakat $3 \mathrm{~kW}$ GES ile $5 \mathrm{~kW}$ GES'lerin geri dönüş sürelerinin yakın olmasının sebebi $5 \mathrm{~kW}$ GES tasarımı yapılan hanenin tükettiği enerjiden fazla enerji üretilmesinden kaynaklıdır (Şekil 5, Şekil 6). Ayrıca $10 \mathrm{~kW}$ GES tasarımı yapılan hanelerde yıllar içinde tüketilen enerji miktarı düşerse santralin geri ödeme süresi artacaktır. Dolayısıyla güneş enerjisine dayalı üretim tesisleri için kişilerin aylık tüketimlerini karşılayacak büyüklükte üretim tesisi kurmasının yatırımın geri dönüşs süresi açısından avantajlı olduğu tespit edilmiştir.

Şekil 7'de elde edilen veriler incelendiğinde Samsun, Bayburt ve Mersin illerine 01.05.2019 tarihinde yapılan santral tasarımlarında 1(bir) yıllık süreçte geri ödeme süresinde yaklaşık \% 41-42'lik düşme meydana gelmiştir. Bunun sebebi 1(bir) yıllık süreçte elektrik tarifelerinde meydana gelen yaklaşık \% 34'lük artış ve 01.05.2019 tarihinde kurulumu yapılan GES'lerin sahipleri bu artış nedeniyle santralin elde ettiği net y1llık gelir artmıştır.

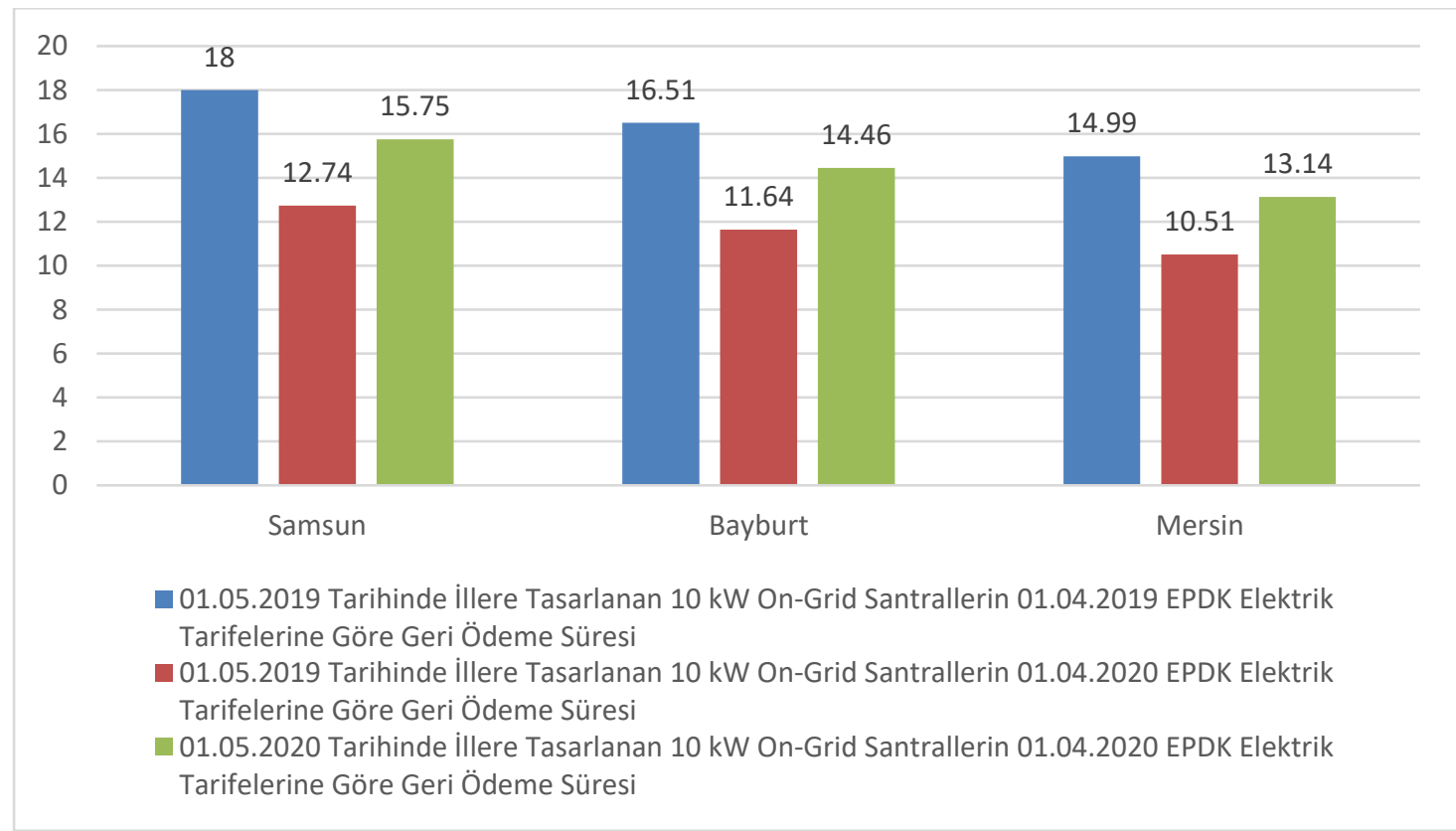

Şekil 8. İllere tasarlanan şebekeye bağlı $10 \mathrm{~kW}$ santrallerin geri ödeme sürelerinin karşılaştırılması [Yıl] 
Şekil 8'de elde edilen veriler incelendiğinde Samsun, Bayburt ve Mersin illerine 01.05.2019 tarihinde yapılan santral tasarımları, 01.05.2020 tarihinde yapılan santral tasarımlarına göre yaklaşık \% 23-25 oranında geri ödeme sürelerinde avantajlı olduğu tespit edilmiştir. Bunun sebebi 1 yıllık süreçte doların yaklaşık \% 17'lik artış göstermesi, elektrik tarifelerinde meydana gelen yaklaşı \% 34'lük artıştır. 01.05.2019 tarihinde kurulumu yapılan GES'lerin sahipleri döviz kurunun ve elektrik tarifelerinde meydana gelen yükselmeden olumlu etkilenmiştir. 01.05.2020 tarihinde kurulumu yapılan GES'ler dövizde meydana gelen artıştan olumsuz etkilenmiştir.

Bir yıllık süredeki dolarda ve enerji fiyatlarındaki değişimler dikkate alındığında, döviz kurunun artması santral tasarım maliyetini arttırmakta fakat enerji fiyatlarındaki artış üreticinin gelirini ve tasarrufunu artıracağından geri ödeme süresini düşürmektedir.

Simülasyon programlarına göre 01.05.2020 tarihinde tasarlanan, $3 \mathrm{~kW}$ şebekeye bağlı GES maliyeti 12.300 Dolar (86.100 TL), $5 \mathrm{~kW}$ şebekeye bağli GES maliyeti 18.900 Dolar (132.300 TL) ve $10 \mathrm{~kW}$ şebekeye bağlı GES maliyeti ise 34.000 Dolar (238.000 TL) olmaktadır [19]. Dolayısıyla $3 \mathrm{~kW}$ kurulu güce sahip santralin birim maliyeti 4.100 Dolar/kW, $5 \mathrm{~kW}$ kurulu güce sahip santralin birim maliyeti 3.780 Dolar $/ \mathrm{kW}$ ve $10 \mathrm{~kW}$ kurulu güce sahip santralin birim maliyeti 3.400 Dolar $/ \mathrm{kW}$ olmaktadır. Matematiksel olarak daha önce yapılan işlemler uygulanırsa Şekil 9'daki geri ödeme süreleri elde edilir.

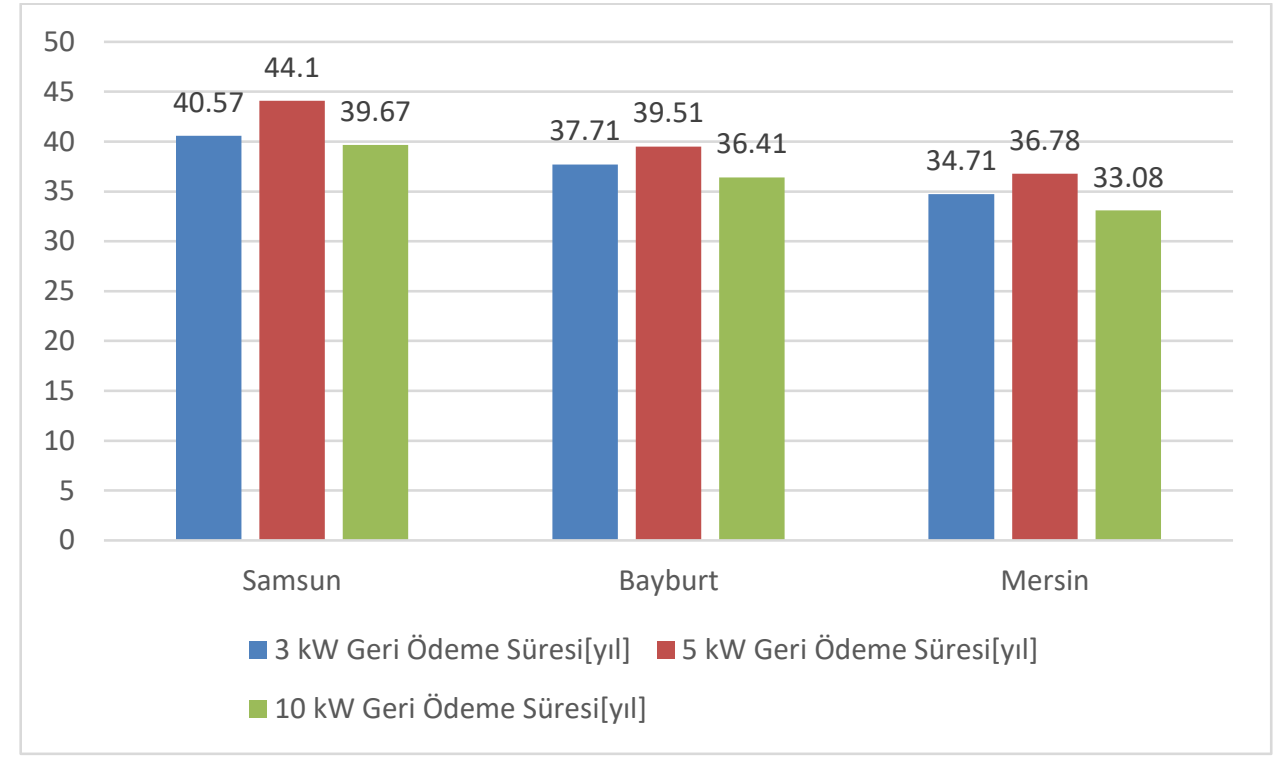

Şekil 9. Simülasyon programlarında illere tasarlanan şebekeye bağll santrallerin geri ödeme süresi [Yıl]

Kullanılan program sonuçlarına göre geri ödeme süresi en düşük sırasıyla; Mersin, Bayburt ve Samsun olmuştur [19]. Şekil 9 incelendiğinde en ideal santral tasarımı $10 \mathrm{~kW}$ ve Samsun ile Mersin arasındaki geri ödeme sürelerinin farkı yaklaşı \%20 olduğu tespit edilmiştir. Şekil 6 ve Şekil 9'da görüldüğü üzere kullanılan simülasyon programları ile yapılan piyasa araştırması sonuçları karşılaştırıldığında geri ödeme sürelerinde 2-3 katlık bir fark olduğu tespit edilmiştir [19].

\section{B. ŞEBEKEDEN BAĞIMSIZ ÇATI TİII GÜNEŞ ENERJISİ SANTRALLERİN KARŞILAŞTIRILMASI}

Simülasyon programlarına göre 01.05.2020 tarihinde tasarlanan, şebekeden bağımsız GES'lerin yaklaşık maliyet ve geri ödeme süreleri Şekil 10 ve Şekil 11'de verilmiştir. 


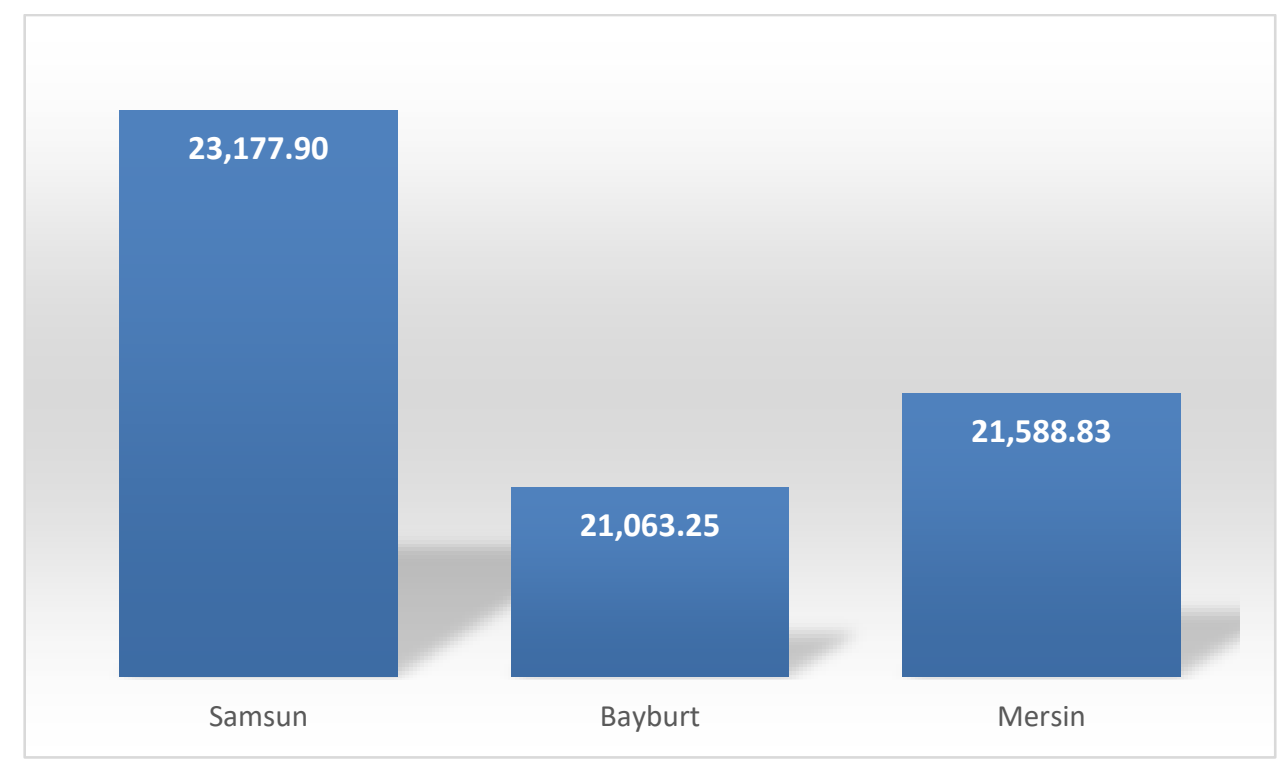

Şekil 10. Simülasyon programlarında illere tasarlanan şebekeden bağımsız santrallerin yaklaşık maliyeti [Dolar] [19]

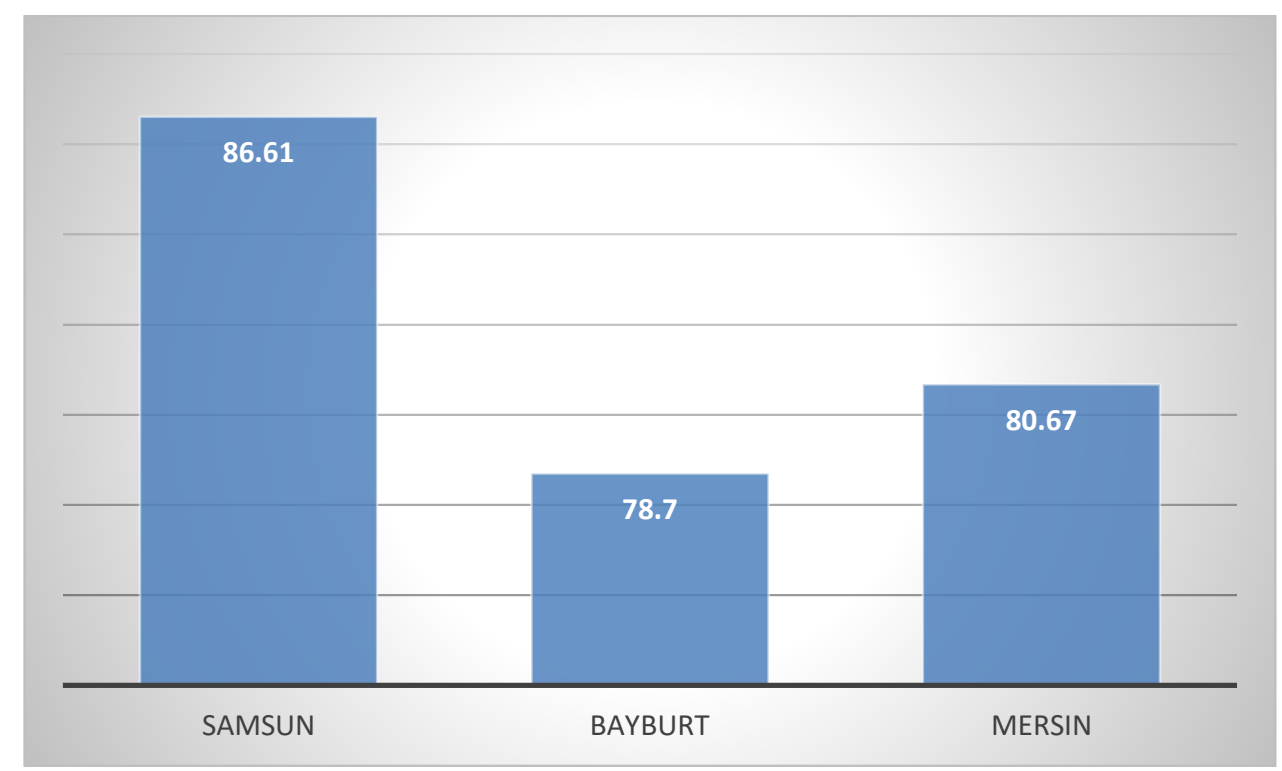

Şekil 11. Simülasyon programlarında illere tasarlanan şebekeden bă̆ımsız santrallerin geri ödeme süreleri [Yll]

Şekil 10 ve Şekil 11 incelendiğinde geri ödeme sürelerine göre en ideal şebekeden bağımsız santral Bayburt iline tasarlanan santral olduğu tespit edilmiştir. Bunun sebebi Bayburt iline yapılan santral tasarımının maliyetinin daha düşük olmasıdır [19]. 
Tablo 1. Matematiksel Modelleme Olarak Tasarlanan Şebekeden Bağımsız Santraller İçin Seçilen Cihazlar

\begin{tabular}{|c|c|c|c|c|c|c|c|c|}
\hline \multirow[t]{2}{*}{ Cihaz } & \multirow[t]{2}{*}{ Kapasite } & \multicolumn{3}{|c|}{ Adet } & \multirow[t]{2}{*}{$\begin{array}{c}\text { Birim } \\
\text { Fiyat }\end{array}$} & \multicolumn{3}{|c|}{ Toplam Fiyat } \\
\hline & & Samsun & Bayburt & Mersin & & Samsun & Bayburt & Mersin \\
\hline FV Modül & $\begin{array}{c}270 \mathrm{~W} \\
\text { (Nominal } \\
24 \mathrm{~V} \\
\text { çıkışl1) }\end{array}$ & 12 & 12 & 8 & 950 & 11.400 & 11.400 & 7.600 \\
\hline Şarj Regülatörü & $\begin{array}{c}48 \mathrm{~V} \text { girişli } \\
50 \mathrm{~A}\end{array}$ & 1 & 1 & 1 & 2.500 & 2.500 & 2.500 & 2.500 \\
\hline Akü & $\begin{array}{c}12 \mathrm{~V} 200 \\
\mathrm{Ah}\end{array}$ & 12 & 12 & 12 & 2.800 & 33.600 & 33.600 & 33.600 \\
\hline Off-Grid invertör & $\begin{array}{c}5000 \\
\text { W/5000 } \\
\text { VA }\end{array}$ & 1 & 1 & 1 & 6.000 & $6.000 \mathrm{TL}$ & 6.000 & 6.000 \\
\hline $\begin{array}{l}\text { Kablo, } \\
\text { konnektör,montaj } \\
\text {,nakliye vb. }\end{array}$ & & 1 & 1 & 1 & 10.000 & 10.000 & 10.000 & 10.000 \\
\hline TOP & LAM & & & & $\begin{array}{c}22.250 \\
\text { TL }\end{array}$ & $\begin{array}{c}63.500 \\
\text { TL }\end{array}$ & $\begin{array}{c}63.500 \\
\text { TL }\end{array}$ & $\begin{array}{c}59.700 \\
\text { TL }\end{array}$ \\
\hline
\end{tabular}

Tablo 1 incelendiğinde şebekeden bağımsız santral tasarımlarında toplam maliyetin yaklaşık \% 4347'lik kısmını aküler oluşturmaktadır.

Matematiksel olarak şebekeden bağımsız santral tasarımlarında illerin kış güneşlenme süreleri hesaba katılarak ve en az 2 gün bulutluluk olduğu varsayılarak güneş paneli, akü ve invertör hesaplamaları yapılmıştır [19]. Samsun ilinde kış güneşlenme süresi ortalama 3,6 saat, Bayburt ilinde 3,53 saat ve Mersin ilinde 4,99 saat olmaktadır [4,19]. Santrallerde kurulu olan 12 adet akü toplam 28.800 Wh / gün elektrik enerjisini depolayabilmektedir.

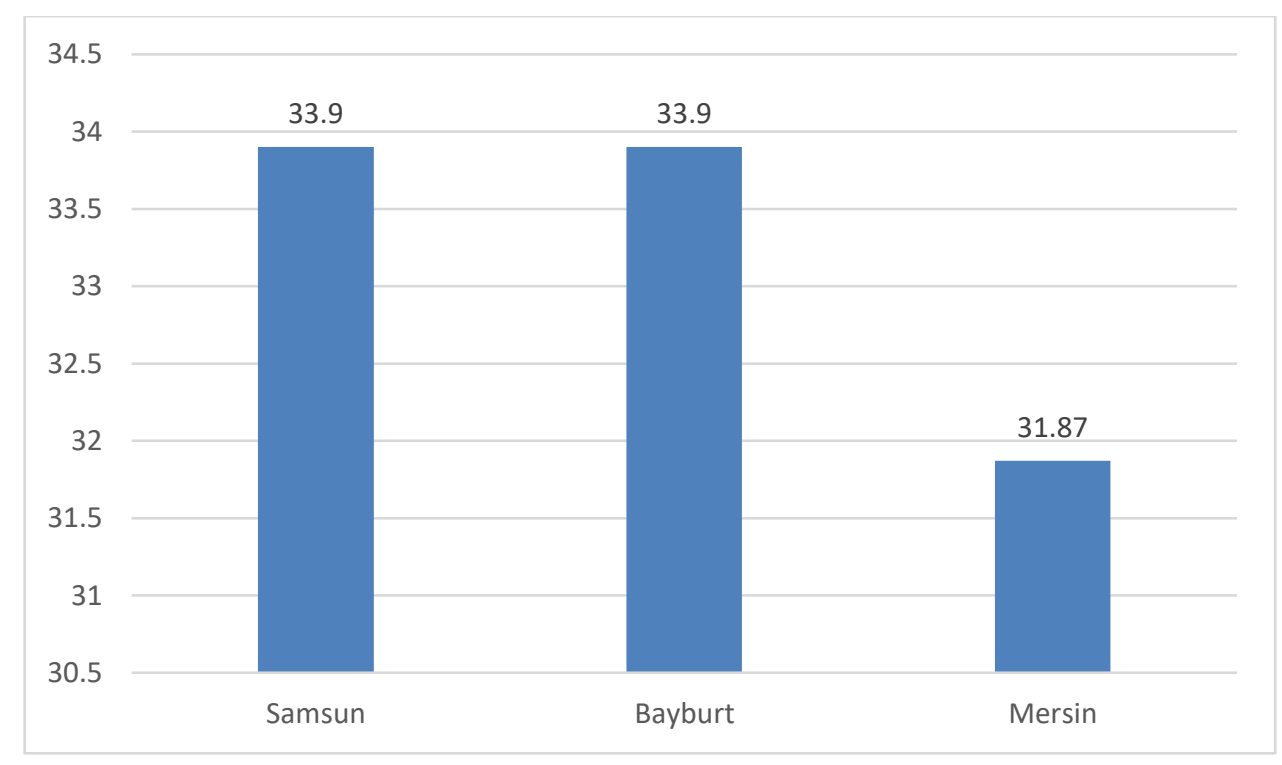

Şekil 12. 01.05.2020 tarihinde illere tasarlanan şebekeden bă̆ımsız santrallerin geri ödeme süreleri (matematiksel modelleme)

1 hanenin günlük 7,224 kWh'lik tüketimini karşılayacak şebekeden bağımsız santral tasarımları daha optimum sonuç almak için 9 kWh/gün seçilmiştir. Şekil 11 ve Şekil 12'de görüldügüü üzere 1 hanenin günlük 7,224 kWh'lik tüketimini karşılayacak şebekeden bağımsız santrallerin geri dönüş süreleri yatırım yapılabilir seviyeden uzak kalmaktadır [19]. Ortalama maliyete y1llık bakım maliyetleri ve ortalama 5-6 yılda bir değişecek akülerin maliyetleri ilk kurulum maliyetinin içinde olmadığı için 
eklenmemiştir. Bu verilere göre şebekeden bağımsız santraller, şebekeye bağlı santrallere göre düşük verimli bulunmuşlardır.

\section{IV.SONUC}

Samsun, Bayburt ve Mersin illerine PVGIS, PVsyst ve HOMER programları ile çeşitli güçlerde şebekeye bağlı ve şebekeden bağımsız çatı tipi GES tasarımları yapılmıştır. Güneş radyasyon oranı en yüksek olan sırasıyla Mersin, Bayburt ve Samsun illerinde elektrik üretim miktarları da aynı sirayla gerçekleşmektedir. Bayburt ili Samsun ilinden yaklaşık \%14,5 yıllık toplam güneş radyasyonuna sahipken, Mersin ili Bayburt ilinden yaklaşık \% 6,3 yıllık toplam güneş radyasyonuna sahiptir. Yıllık GES'lerin üretimleri ve geri dönüş sürelerine bakıldığında; iller arasındaki yıllık net toplam elektrik üretimi arasındaki fark sırasıyla \% $12-13$, geri ödeme süreleri arasındaki fark sırasıyla $1-2$ yıl olduğu tespit edilmiştir. Dolayısıyla Türkiye'nin 7(yedi) bölgesi de güneş enerjisi alanında verimli bulunmuştur. Güneş enerjisi alanında lider ülkelerden biri olan Almanya'nın güneş radyasyon oranı Karadeniz Bölgesi'nde bulunan illere yakın olduğu düşünüldüğünde Türkiye güneş enerjisi potansiyelini tam olarak kullanamadığı ortaya çıkmaktadır. Güneş enerjisi karbon salınımı olmayan ve sürekliliği olan yenilenebilir enerji olduğu için elektrik üretiminde bu alana yatırım yapılması zorunluluktur.

Yapılan simülasyon ve matematiksel tasarımlar karşılaştırıldığında 3 il için de aylık ve yıllık mahsuplaşma için en ideali $10 \mathrm{~kW}$ 'llk şebekeye bağlı GES tasarımı olduğu tespit edilmiştir. Dolayısıyla güneş enerjisine dayalı üretim tesisleri için kişilerin aylık tüketimlerini karşılayacak büyüklükte ve birim maliyeti düşük olan üretim tesisi kurmasının yatırımın geri dönüş süresi açısından avantajlı olduğu tespit edilmiștir. Kullanılan simülasyon programlarında elde edilen yaklaşık maliyet, yapılan piyasa araştırması sonucu elde edilen maliyetin 2-3 katı olduğu tespit edilmiştir. Elektrik tüketimi yüksek olan haneler için şebekeden bağımsız GES verimsiz olduğu tespit edilmiş fakat şebekenin olmadığı ve düşük güçte tüketimin olduğu meskenler için ideal bir çözüm olarak değerlendirilebilir bulunmuştur.

01.05.2019 ve 01.05.2020 tarihlerinde yapılan piyasa araştırmasına göre tasarlanan GES'ler incelendiğinde; 01.05.2019 tarihinde tasarlanan GES'ler geri ödeme süreleri açısından daha avantajlı olduğu tespit edilmiştir. Bunun sebebi döviz kurunun artması 01.05.2020 tarihinde kurulan santral tasarım maliyetini arttırması ve enerji fiyatlarındaki artışın üreticinin gelirini ve tasarrufunu arttırdığından geri ödeme süresini düşürmesidir. İllere tasarlanan $10 \mathrm{~kW}$ GES'lerin geri ödeme süreleri 01.05.2020 tarihi itibariyle 10-16 yıl aralığında olduğundan yatırım yapılabilir seviyeden uzak kalmaktadır.

Döviz kurlarının artması, GES bileșenlerinin ithalata bağımlı olması ve Ülkemizde güneș enerjisi ARGE çalışmalarının istenilen seviyede olmaması nedeniyle ilk girdi maliyetinin artması yatırımları olumsuz etkilemektedir. Enerji fiyatlarındaki enflasyondan etkilenilmeyeceğinden yıllar içinde geri ödeme sürelerinde düşüş yaşanacak olması cazip yanıdır.

Çatı ve cephe tipi GES'e yönelimlerin artması için; GES teknolojisi alanında AR-GE yatırımları desteklenerek ilk yatırım maliyetlerinde en yüksek paya sahip olan FV modül ve invertör fiyatlarının düşmesine katkı sağlanmalı, GES bileşenlerinin dövize olan bağlılı̆̆ azaltılmalı, ithalatın azalması ve geri ödeme sürelerinin 5-6 yıl seviyelerine düşmesi gerekmektedir.

Türkiye'nin güneş enerjisi potansiyelini istenilen düzeyde kullanamadığ tespit edilmiş ve vatandaşların güneş enerjisine katkısının en kolay yolu olan çatı ve cephe tipi GES'ler incelenmiştir. Bu alanın gelişmesi için çeşitli öneriler verilmiştir. Bu çalışma ile yatırımların Türkiye geneline yayılmasına, enerji arz güvenliği sağlanmasına ve güneş enerjisinin gelişmesine katkı sağlanabileceği düşünülmektedir. 


\section{KAYNAKLAR}

[1] “IEAWorld Energy Outlook 2013,” International Energy Agency (IEA), 2013.

[2] “BP Energy Outlook 2017 Edition,” British Petroleum (BP), 2017.

[3] H. Öztürk ve D. Kaya, Güneş Enerjisinden Elektrik Üretimi : Fotovoltaik Teknoloji, 1. bask1, Kocaeli, Türkiye: Umuttepe Yayınları, 2013, ss. 1-417.

[4] A. Yiğit ve İ. Atmaca, Güneş Enerjisi Mühendislik Uygulamaları, 2. baskı, Bursa, Türkiye: Dora Yayınc1lık, 2018, ss. 1-263.

[5] Makine Mühendisleri Odası (MMO), “Türkiye’nin Enerji Görünümü 2018,” MMO Yayın No 691, 2018.

[6] Elektrik Piyasasında Lisanssız Elektrik Üretimine İlişkin Yönetmelikte Değişiklik Yapılmasına Dair Yönetmelik, T.C. Enerji Piyasası Düzenleme Kurumu, 2018. [Çevrimiçi]. Erişim: https://www.epdk.gov.tr/Detay/Icerik/3-0-92/elektriklisanssiz-uretim

[7] 10.05.2019 Tarih ve 30770 Sayılı Resmi Gazete, T.C. Cumhurbaşkanlığı, 2019. [Çevrimiçi]. Erişim: https://www.resmigazete.gov.tr/eskiler/2019/05/20190510.pdf

[8] T. K. Geoffrey ve T. S. Joshua, "Models Used to Assess the Performance of Photovoltaic Systems," Sandia Rep., c. SAND2009-8258, 2009.

[9] R. Çakmak, ve İ. H. Altaş, "Solar energy potential of eastern black sea region of Turkey: A case study for Trabzon Province," in 2016 National Conference on Electrical, Electronics and Biomedical Engineering, Bursa, Turkey, 2016, ss. 86-90.

[10] C. Haydaroğlu ve B. Gümüş, "Dicle Üniversitesi Güneş Enerjisi Santralinin PVsyst İle Simülasyonu Ve Performans Parametrelerinin Değerlendirilmesi," Mühendislik Dergisi, Dicle Üniversitesi Mühendislik Fakültesi, c. 7, s. 3, ss. 491-500, 2016.

[11] Md. Nurunnabi ve N.K. Roy, "Grid Connected Hybrid Power System Design Using HOMER," Proceedings of 2015 3rd International Conference on Advances in Electrical Engineering, Dhaka, Bangladesh, 2015, ss. 18-21.

[12] A. Rohani, K. Mazlumi ve H. Kord, "Modeling of a hybrid power system for economic analysis and environmental impact in HOMER," Proceedings of ICEE, 2010, ss. 818-822.

[13] P. Yadav, N. Kumar ve S.S. Chandel, "Simulation And Performance Analysis Of A 1 kwp Photovoltaic System Using Pvsyst," Internatıonal Conference On Computatıon Of Power, Energy, Information And Communication, 2015, ss. 358-363.

[14] C.P. Kandasamy, P. Prabu ve K. Niruba, "Solar Potential Assessment Using PVSYST Software," 2013 International Conference on Green Computing, Communication and Conservation of Energy (ICGCE), 2013, ss. 667-672.

[15] C.S. Psomopoulos, G.C. Ioannidis, S.D. Kaminaris, K.D. Mardikis ve N.D. Katsikas, "A Comparative Evaluation Of Photovoltaic Electricity Production Assessment Software (PVGIS, PVWATTS And RETSCREEN)," Department of Electrical Engineering, Piraeus University of Applied Sciences, Greece, 2015, ss. 175-189. 
[16] O. Ceylan ve K. Taşdelen, "Isparta İli İçin Fotovoltaik Programlarının Simülasyon Sonuçlarının Doğruluğunun İncelenmesi," Afyon Kocatepe Üniversitesi Fen ve Mühendislik Bilimleri Dergisi, c. 18, s. 3, ss. 895-903, 2018.

[17] C. Dondariya, D. Porwal, A. Awasthi, A.K. Shukla, K. Sudhakar, M.S.R. Monahar ve A. Bhimte, "Performance Simulation Of Grid-Connected Rooftop Solar PV System For Small Households: A Case Study Of Ujjain, India,” Energy Reports, c. 4, ss. 546-553, 2018.

[18] Enerji İşleri Genel Müdürlügüü. (2020, 15 Mayıs). "Güneş Enerjisi Potansiyel Atlası (GEPA).” [Çevrimiçi]. Erişim: https://gepa.enerji.gov.tr/MyCalculator/

[19] S. Akkaya, "Samsun, Bayburt ve Mersin illerine kurulabilecek güneş enerjisi santrallerinin modellenmesi", Yüksek lisans tezi, Yenilenebilir Enerji Anabilim Dalı, Ordu Üniversitesi, Ordu, Türkiye, 2019.

[20] Elektrik Piyasasında Lisanssiz Elektrik Üretim Yönetmeliği, T.C. Enerji Piyasası Düzenleme Kurumu, 2019. [Çevrimiçi]. Erişim: https://www.epdk.gov.tr/Detay/Icerik/3-0-92/elektriklisanssizuretim

[21] Dağıtım Lisansı Sahibi Tüzel Kişiler Ve Görevli Tedarik Şirketlerinin Tarife Uygulamalarına İlişkin Usul Ve Esaslarda Değişiklik Yapılması Hakkında Karar, T.C. Enerji Piyasası Düzenleme Kurumu, 2019. [Çevrimiçi]. Erişim: https://www.epdk.gov.tr/Detay/Icerik/3-10284/dagitim-lisansisahibi-tuzel-kisiler-ve-gorevli-t

[22] 26.03.2020 Tarih ve 9270 Sayıl Kurul Kararl, T.C. Enerji Piyasası Düzenleme Kurumu, 2020. [Çevrimiçi]. Erişim: https://www.resmigazete.gov.tr/eskiler/2020/03/20200331-4.pdf

[23] 27.03.2019 Tarih ve 8518 Sayll Kurul Kararl, T.C. Enerji Piyasası Düzenleme Kurumu, 2019. [Çevrimiçi]. Erişim: https://www.lexpera.com.tr/mevzuat/kurul-kararlari/enerji-piyasasi-duzenlemekurulunun-27-03-2019-tarihli-ve-8518-sayili-karari-8518-1 